\title{
Optimization of Embung Jinggring for Water Resources Development of the Sadar Watershed, Mojokerto, East Java
}

\author{
Reja Putra Jaya ${ }^{1^{*}}$ \\ 'Universitas Janabadra, Yogyakarta, INDONESIA \\ *Corresponding authors: rejaputrajaya@yahoo.co.id
}

SUBMITTED 20 November 2018 REVISED 25 December 2018 ACCEPTED 15 January 2019

\begin{abstract}
Embung is a small reservoir which can reserve water exceeds during the rainy season and utilize it on dry season. It is utilized for many purposes, such as providing water for agricultural purposes, fishery, and household needs. Jinggring Weir which is located at Mojokerto Regency, East Java Province is planned to enhance as embung to be able to provide higher water demand services. An appropriate method of water demand optimization study is important for reservoir water management operation to estimate water supply reliability both used for irrigation as well as domestic water. The Mock method was used to analyze water availability, while irrigation, and domestic water requirement, global water balance, simulation of the reservoir operation was analyzed based on Standard Operating Rule (SOR) method. The linear program method is used to determine an appropriate amount of water released to reach the optimum value of water supply reliability. The result of the simulation of target released using SOR method showed that the embung reliability for irrigation and domestic purpose increased from $81.55 \%$ to $100 \%$ and $80.09 \%$ to $100 \%$, respectively.
\end{abstract}

KEYWORDS Optimization; linear program; reservoir operation; Mock method.

(c) The Author(s) 2018. This article is distributed under a Creative Commons Attribution-ShareAlike 4.0 International license.

\section{INTRODUCTION}

Embung is a small reservoir type used to reserve water exceed during the rainy period and utilize it during dry period for agricultural or other water usages. It is utilized to irrigate the agricultural land, especially during the dry period. Another purpose is to fulfill domestic water demand and fishery cultivation. An Embung located at Mojokerto Regency, East Java Province, named Embung Jinggring with the catchment area of $\pm 8.74 \mathrm{~km}^{2}$ was planned to be constructed to enlarge and acts as a small dam with the reservoir to conserve water to fulfill larger water demand services. An appropriate method of water demand optimization study is determined for reservoir water management operation. This research is expected to provide such information and recommendation for water supply reliability both used for irrigation as well as domestic water. Through utilization optimization of Embung Jinggring is intended to gain maximum uses for water source potential.

\section{OPTIMIZATION OF WATER RESOURCES UTILIZATION}

Several studies related to the utilization of reservoir water resources have been widely practiced. Tarigan (2001) conducted a study on water utilization optimization of Kedung Ombo Dam to meet the needs of irrigation water, domestic water, and hydropower using linear program method. The study aims to optimize the water utilization from Kedung Ombo Dam. Setiawan (2007) conducted a reliability study of Sempor Reservoir which is a multipurpose reservoir by utilizing water resources for various community needs, namely irrigation, domestic, industrial and hydropower. Analysis of the research was carried out by reservoir operation simulation and application of water allocation optimization techniques. Thus, water demand fulfillment factor ( $k$ factor) is an indicator of the success of reservoir operations. Gunawan (2005) conducted a study to determine the operating pattern of a series reservoir system that can provide optimum electrical energy results while considering the sustainability of the reservoir so that maximum water utilization can be achieved. Hartini (2013) conducted a study on optimizing water regulation of Pandanduri 
Reservoir using linear program method for the fulfillment of irrigation water needs of Palung and Gambir irrigation channel with the potential of additional water availability in irrigation system land that is return flow.

Optimization of water resource utilization must concern the purpose of water utilization. It is used to review and evaluate alternative development and utilization of water resources by means of a system approach that aims to review and evaluate in detail (Rahmadana, 2013). Louck, et al. (1981) suggested that the approach in water resources planning and development consists of simulation methods, optimization and a combination of the two. Simulation is a method that is often used in a model approach to real natural phenomena, meaning that simulation is a model of the system behavior.

The use of mathematical models as an analytical tool for designing optimal water resources utilization is a commonly used method. Decision makers in the development and utilization of water resources often consider makes optimal decisions by approaching system engineering and system analysis (Jayadi, 2000).

\section{BASIC THEORY}

\subsection{Evapotranspiration}

Potential evapotranspiration is evaporation of water absorbed from vegetated surfaces, where groundwater is absorbed by plant roots and flows through the stem to the surface of the leaves and evaporate into the atmosphere. Evaporation analysis in this study was used as a water loss (outflow) for pond water regulation simulation using the Penman method described in Equation (1) - Equation (3) (Triatmodjo, 2008).

$$
\begin{aligned}
& E_{t}=\frac{\beta E_{n}+E_{0}}{\beta+1} \\
& E_{n}=\frac{R_{n}}{\rho_{w} I_{v}} \\
& E_{0}=0.35\left(0.5+0.54 u_{2}\right)\left(e_{s}-e_{d}\right)
\end{aligned}
$$

within $E_{t}$ is potential evapotranspiration ( $\mathrm{mm} /$ day), $E_{n}$ : is the depth of evapotranspiration $\left(\mathrm{mm} /\right.$ day), $E_{0}$ is evaporation ( $\mathrm{mm} /$ day), $\beta$ is the value of temperature function $R_{n}$ is radiation net (cal/ $/ \mathrm{cm}^{2} /$ day) $I_{v}$ is latent heat evaporation (cal./gr), $\rho_{w}$ is water mass meeting $\left(\mathrm{gr} / \mathrm{cm}^{3}\right), U_{2}$ is wind velocity $(\mathrm{m} / \mathrm{s}), e_{s}$ is saturated pressure $(\mathrm{mm} \mathrm{Hg})$, and $e_{s}$ is air pressure $(\mathrm{mm} \mathrm{Hg})$.

\subsection{Irrigation Water Needs}

According to Irrigation Standards Planning Criteria-01 (Direktorat Jendral Pengairan, 2010), the amount of water demand supplied by Embung Jinggring needs to be determined by considering the potential availability of water based on rainfall data. The reduction factor is determined based on a comparison of the records of the primary channel discharge for each irrigation area with the need for irrigation water at the intake for the half month period. Calculation of irrigation water requirements is shown in Equation (4).

$$
K A I=\left[\frac{E T_{c}+I R+W_{i r}+P-R_{e}}{E I}\right] \times A
$$

within $K A I$ is irrigation water needs $\left(\mathrm{m}^{3} / \mathrm{s}\right), E T c$ is consumptive water needs ( $\mathrm{mm} /$ day), $I R$ is water needs for land processing (mm/day), $W_{i r}$ is water requirements for layer replacement water ( $\mathrm{mm} /$ day), $P$ is percolation ( $\mathrm{mm} /$ day), $R e$ is effective rainfall (mm/day), $E I$ is irrigation efficiency (\%), and $A$ is irrigation area (ha).

\subsection{Domestic Water}

In this study, the calculation of raw water requirements for Embung Jinggring will be expected to be able to meet the needs of raw water in the 4 villages around the Embung Jinggring area plan. According to Prasetyo (2000), raw water requirements can be calculated using Equation (5) and Equation (6).

$$
\begin{aligned}
& K A=\frac{P . S .30}{1000} \\
& P_{n}=P_{0}(1+r)^{n}
\end{aligned}
$$

within $K A$ is domestic water needs $\left(\mathrm{m}^{3} /\right.$ month), $P$ is population (man), $S$ is standard water need ( $\mathrm{l} / \mathrm{man} /$ day), $P_{n}$ is population in year period - $\mathrm{n}(\mathrm{man})$, $P_{0}$ is population initial year (man), $r$ is rate population rate (\%), and $n$ is the number of years.

Standard water requirements according to the Guidelines for Domestic Water and Industrial Water Needs (Direktorat Bina Teknik, 2003) are as follows.
a) province
: 120 litre/man/day.
b) districts
: 100 litre/man/day.
c) sub districts
d) village
: 80 litre/man/day.
: 60 litre/man/day.

\subsection{Water Availability}

Approach analysis of water availability in a watershed can use rainfall diversion, the flow of the Mock method 
(1973). This method serves to predict the availability of water in a watershed that is commonly used as an average inflow of a reservoir for the simulation of embung water balance. Meanwhile, for the water balance simulation, the existing inflow condition uses mainstay discharge $\left(\mathrm{Q}_{80}\right)$.

\subsection{Linear Program Method for Optimization}

The linear program is an analytical optimization modeling technique, wherein the analytical procedure uses a mathematical model, with the aim of finding the optimal problem solving (maximizing or minimizing) and the requirements formulated as constraint functions in the form of inequality and similarity of linear functions. The linear program is a mathematical model that is quite popular and has long been applied in the optimization analysis of water resources (Jayadi, 2012). Optimization analysis in this research used Excel Solver Program.

\section{RESEARCH METHODS}

\subsection{Flowchart Research}

Data analysis and research stages were conducted in accordance with the research flow are shown in Figure 1.

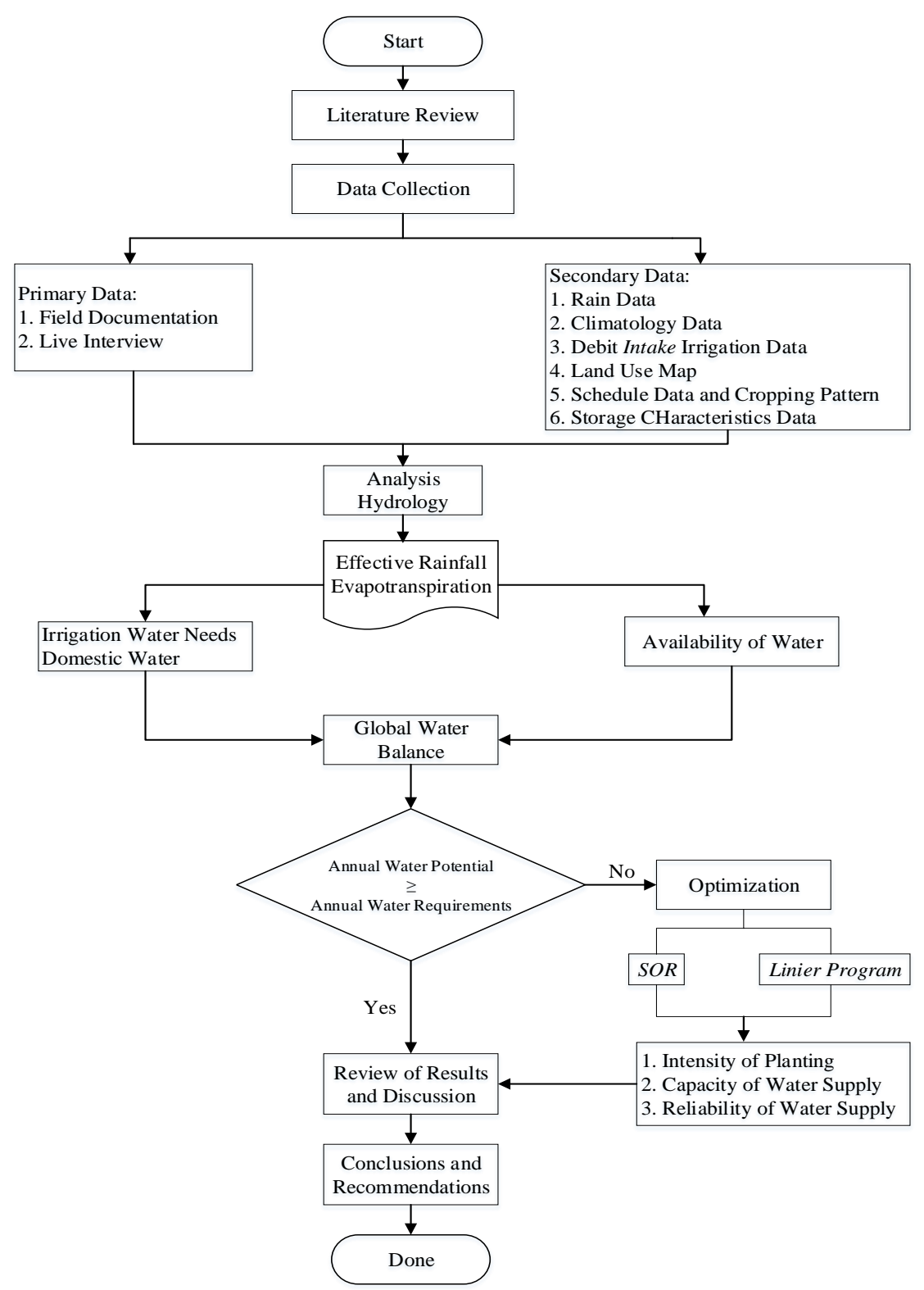

Figure 1. Flowchart research. 


\section{RESULTS AND DISCUSSION}

\subsection{Average Rainfall Analysis}

By using the Thiessen Polygon Method, monthly rainfall in whole Sadar Watershed is presented in Table 1 below.

Table 1. Watershed monthly rainfall $(\mathrm{mm})$

\begin{tabular}{lllllllllllllll}
\hline No. & Year & Jan & Feb & Mar & Apr & May & Jun & Jul & Aug & Sep & Oct & Nov & Dec \\
\hline 1 & 2007 & 172 & 644 & 582 & 316 & 7 & 63 & 16 & 0 & 0 & 0 & 9 & 15 \\
2 & 2008 & 329 & 579 & 494 & 98 & 45 & 3 & 0 & 1 & 0 & 87 & 250 & 388 \\
3 & 2009 & 554 & 399 & 316 & 110 & 345 & 58 & 0 & 0 & 0 & 1 & 140 & 194 \\
4 & 2010 & 601 & 504 & 350 & 418 & 202 & 94 & 17 & 59 & 147 & 193 & 198 & 520 \\
5 & 2011 & 515 & 333 & 264 & 329 & 211 & 53 & 15 & 1 & 0 & 18 & 329 & 290 \\
6 & 2012 & 470 & 354 & 222 & 123 & 71 & 62 & 20 & 1 & 0 & 4 & 90 & 149 \\
7 & 2013 & 165 & 185 & 197 & 65 & 92 & 122 & 48 & 2 & 1 & 0 & 131 & 154 \\
8 & 2014 & 432 & 448 & 282 & 357 & 116 & 114 & 85 & 0 & 1 & 0 & 85 & 436 \\
9 & 2015 & 399 & 269 & 446 & 209 & 120 & 116 & 87 & 0 & 1 & 0 & 88 & 440 \\
\hline
\end{tabular}

\subsection{Evaporation}

Evapotranspiration analysis is one of the bases for calculating the value of irrigation water needs, whereas evaporation will be used to determine the amount of water loss caused by evaporation of the reservoir. The results of evapotranspiration and evaporation calculations are presented in Table 2.

Table 2. The results of evaporation and evapotranspiration analysis

\begin{tabular}{llllll}
\hline No & Month & Eo $(\mathrm{mm})$ & No & Month & $\begin{array}{l}\text { ETo } \\
(\mathrm{mm})\end{array}$ \\
\hline 1 & Jan & 136 & 1 & Jan & 131 \\
2 & Feb & 125 & 2 & Feb & 119 \\
3 & Mar & 143 & 3 & Mar & 135 \\
4 & Apr & 105 & 4 & Apr & 116 \\
5 & May & 106 & 5 & May & 118 \\
6 & Jun & 95 & 6 & Jun & 105 \\
7 & Jul & 103 & 7 & Jul & 115 \\
8 & Ags & 131 & 8 & Ags & 131 \\
9 & Sep & 156 & 9 & Sep & 141 \\
10 & Oct & 180 & 10 & Oct & 163 \\
11 & Nov & 157 & 11 & Nov & 151 \\
12 & Des & 141 & 12 & Des & 128 \\
\hline
\end{tabular}

\subsection{Analysis of Watershed Sadar Availability}

Analysis of Watershed Sadar availability used Mock method (1973). Based on Figure 2, it could be seen that the highest average monthly water supply is in the second half of February, whereas the lowest water availability potential occurred in the second half of November. The dependable continuous flow $\left(\mathrm{Q}_{80}\right)$ of the Sadar Watershed is shown in Figure 3 which equals $0.0751 \mathrm{~m}^{3} / \mathrm{s}$.

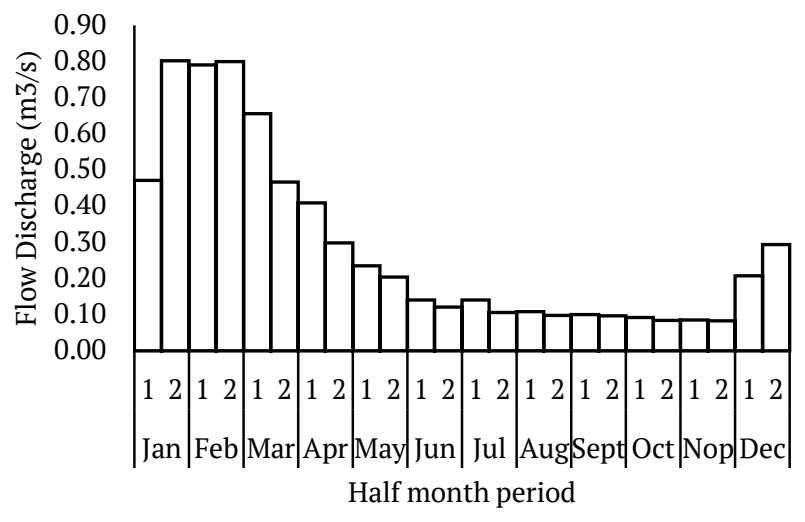

Figure 2. Potential of water availability in Sadar Watershed.

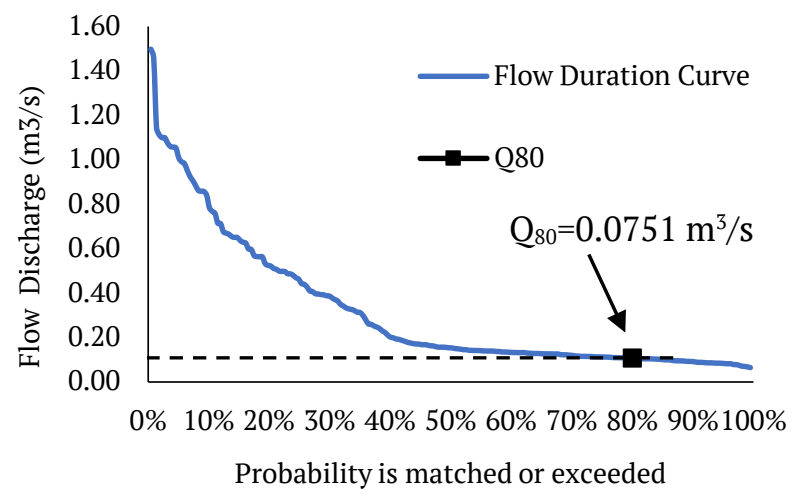

Figure 3. The flow duration curve of Sadar Watershed.

\subsection{Domestic Water Requirement Analysis}

The result of domestic water demand analysis based on the projection of population until the year 2036 is about 11,212 people which is about $0.016 \mathrm{~m}^{3} / \mathrm{s}$. 


\subsection{Analysis of Irrigation Water Needs}

Embung Jinggring is expected to serve the irrigation water needs at 4 (four) irrigation area. It is necessary to calculate the irrigation water requirement in the irrigation area by using the Criteria of Irrigation Planning Standard (Direktorat Jendral Pengairan, 2010). The planting period (MT) of each irrigation area supplied from Embung Jinggring begins in December. The need for irrigation water supplied from this intake can be seen in Table 3 .

Table 3. Medium irrigation water supply monthly

\begin{tabular}{llllll}
\hline $\begin{array}{l}\text { Half } \\
\text { month }\end{array}$ & $\begin{array}{l}\text { MT I } \\
\mathrm{m}^{3} / \mathrm{s}\end{array}$ & $\begin{array}{l}\text { Half } \\
\text { month }\end{array}$ & $\begin{array}{l}\text { MT-II } \\
\mathrm{m}^{3} / \mathrm{s}\end{array}$ & $\begin{array}{l}\text { Half } \\
\text { month }\end{array}$ & $\begin{array}{l}\text { MT III } \\
\mathrm{m}^{3} / \mathrm{s}\end{array}$ \\
\hline Dec I & 0.152 & Apr I & 0.172 & Agt I & 0.125 \\
Dec II & 0.296 & Apr II & 0.283 & Agt II & 0.133 \\
Jan I & 0.243 & May I & 0.259 & Sep I & 0.093 \\
Jan II & 0.237 & May II & 0.238 & Sep II & 0.133 \\
Feb I & 0.244 & Jun I & 0.233 & Oct I & 0.192 \\
Feb II & 0.246 & Jun II & 0.234 & Oct II & 0.198 \\
Mar I & 0.217 & Jul I & 0.194 & Nov I & 0.140 \\
Mar II & 0.113 & Jul II & 0.098 & Nov II & 0.027 \\
\hline
\end{tabular}

\subsection{Water Balance of Embung Jinggring}

\subsubsection{Water Balance Condition without Embung}

A water balance in Sadar Watershed without considering the existence of Embung Jinggring in this research is defined as a ratio of water availability $\left(\mathrm{Q}_{80}\right)$ and irrigation water need. The need for irrigation is calculated based on serviced plant area of Embung Jinggring. According to Figure 4, there was deficit cumulative volume which was estimated approximately -1.105 MCM in the mid of November. Thus, the existence of reservoir is considered essential for fulfilling the water demands.

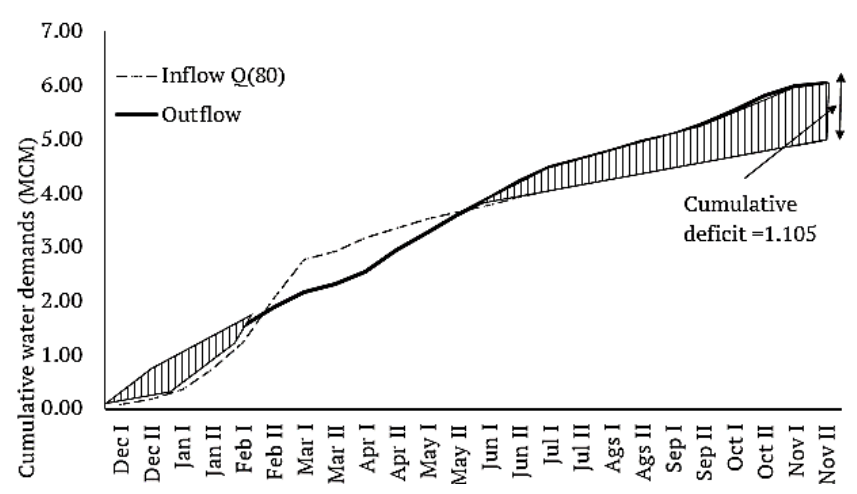

Figure 4. Water balance without embung

\subsubsection{Water Balance Condition with Embung}

The construction of Embung Jinggring is expected to provide enough water supply for irrigation in 4 irrigation area. It is also intended to fulfill raw water need in 4 villages surrounding embung until 2036. The condition of water balance considering the existence of Embung Jinggring is shown in Figure 5. According to Figure 5, the volume of water availability (inflow) sourced from embung is larger than water demand, both for irrigation and raw water need (outflow). Thus, it can be concluded that the existence of Embung Jinggring can provide designated water demand.

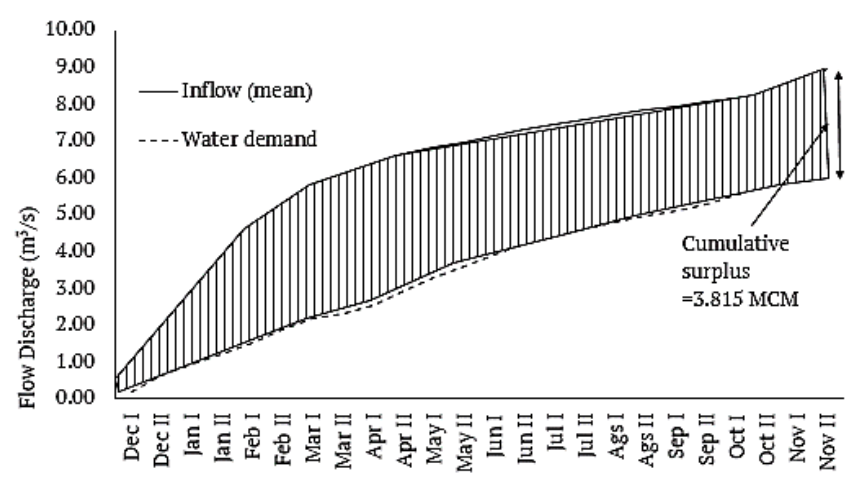

Figure 5. Water balance considering embung

\subsection{Operating Simulation of Embung Jinggring}

In the simulation model by using SOR (Standard Operating Rule), the target release is divided into two purposes, namely irrigation water need and raw water need. It is aimed to give the irrigation water need as the first priority which has to be fulfilled prior to raw water need. The followings are the technical data of Embung Jinggring design:

a) Reservoir capacity volume is $1.656 \mathrm{MCM}$.

b) Dead storage volume is 0.067 MCM.

c) Water surface elevation at maximum capacity is $+352 \mathrm{~m}$

d) Elevation of spillway $+348.86 \mathrm{~m}$

e) Water surface elevation at dead storage is $+342 \mathrm{~m}$.

\subsection{Simulation Results of Release Water Discharge}

Simulation of irrigation water needs in accordance with the plant area and the domestic water requirements plan. Simulation of release water discharge is using the SOR method. In this simulation, the target of domestic water requirement is adjusted so that the reliability of embung for the fulfillment of irrigation water service and minimum water can achieve $95 \%$ of reliability with a variation of reliability factor from $\mathrm{k}=0.70-1.00$ and interval increase to 0.05 . Based on simulation result with the SOR method, it shows that embung design with a reservoir capacity of 1,656 million $\mathrm{m}^{3}$ has an effective volume of 1,595 million $\mathrm{m}^{3}$. The reliability result of embung for the fulfillment of irrigation water and domestic water with 
a variation of the value of water supply reliability factor $(k)$ presented at Table 4.

Table 4. Simulation results of release water adjustment

\begin{tabular}{llll}
\hline No. & $\begin{array}{l}\text { Reliability } \\
\text { factor }(k)\end{array}$ & $\begin{array}{l}\text { Reliability for } \\
\text { irrigation } \\
\text { water (\%) }\end{array}$ & $\begin{array}{l}\text { Reliability for } \\
\text { raw water (\%) }\end{array}$ \\
\hline 1 & 0.70 & 82.41 & 80.09 \\
2 & 0.75 & 82.41 & 80.09 \\
3 & 0.80 & 82.41 & 80.09 \\
4 & 0.85 & 81.48 & 80.09 \\
5 & 0.90 & 81.02 & 80.09 \\
6 & 0.95 & 81.02 & 80.09 \\
7 & 1.00 & 80.09 & 80.09 \\
\hline \multicolumn{2}{l}{ Average } & 81.55 & 80.09 \\
\hline
\end{tabular}

Based on simulation result with SOR method, Embung Jinggring can fulfill irrigation water demand with the average reliability $81.55 \%$ for irrigation with 237 ha and $80.09 \%$ for 4 villages which is planned from 2016 to 2036. The result of simulation cannot meet the target as planned, thus further analysis is needed by optimizing linear program so that the target of water reliability of irrigation and planned water can be achieved.

\subsection{Analysis of Release Water Optimization}

Based on the results of optimization with the linear program method, it shows there was improvement comparing the simulation result of release water and SOR method. Variation of the reliability factor $(k)$ is similar to that applied to the water regulation simulation of the SOR method of 0.70-1.00. The overall water supply reliability is increased from $81.55 \%$ to $100 \%$ for irrigation water, and from $80.09 \%$ to $100 \%$ for raw water.

\subsubsection{Results of Simulation using SOR Method based on Generation of Inflow Data}

Based on the simulation results which used inflow data generated by Thomas Fiering method, Embung Jinggring can serve irrigation water need and raw water need until the next 20 years with the $87.10 \%$ reliability for irrigation and $86.71 \%$ reliability for raw water.

\subsection{The scenario of Flow Discharge Classification}

The obtained pattern of flow discharge is optimized using linear program. Figure 6 and Table 5 show the classification of flow discharge data within 9 years.
Table 5. The scenario of the Classification of Flow Discharge

\begin{tabular}{|c|c|c|c|}
\hline \multirow{2}{*}{ Month } & \multicolumn{3}{|l|}{ Year } \\
\hline & Wet & Normal & Dry \\
\hline Jan I & 0.332 & 0.582 & 0.457 \\
\hline Jan II & 0.580 & 0.885 & 0.969 \\
\hline Feb I & 0.931 & 0.878 & 0.407 \\
\hline Feb II & 0.816 & 0.846 & 0.682 \\
\hline Mar I & 0.535 & 0.670 & 0.810 \\
\hline Mar II & 0.706 & 0.392 & 0.259 \\
\hline Apr I & 0.524 & 0.405 & 0.243 \\
\hline Apr II & 0.386 & 0.277 & 0.212 \\
\hline May I & 0.157 & 0.339 & 0.143 \\
\hline May II & 0.219 & 0.245 & 0.100 \\
\hline Jun I & 0.175 & 0.134 & 0.102 \\
\hline Jun II & 0.132 & 0.123 & 0.098 \\
\hline Jul I & 0.127 & 0.143 & 0.152 \\
\hline Jul II & 0.115 & 0.107 & 0.087 \\
\hline Aug I & 0.118 & 0.110 & 0.089 \\
\hline Aug II & 0.106 & 0.099 & 0.080 \\
\hline Sept I & 0.109 & 0.102 & 0.082 \\
\hline Sept II & 0.105 & 0.098 & 0.079 \\
\hline Oct I & 0.101 & 0.094 & 0.076 \\
\hline Oct II & 0.091 & 0.085 & 0.069 \\
\hline Nov I & 0.093 & 0.087 & 0.070 \\
\hline Nov II & 0.089 & 0.084 & 0.068 \\
\hline Dec I & 0.358 & 0.167 & 0.065 \\
\hline Dec II & 0.154 & 0.408 & 0.274 \\
\hline
\end{tabular}

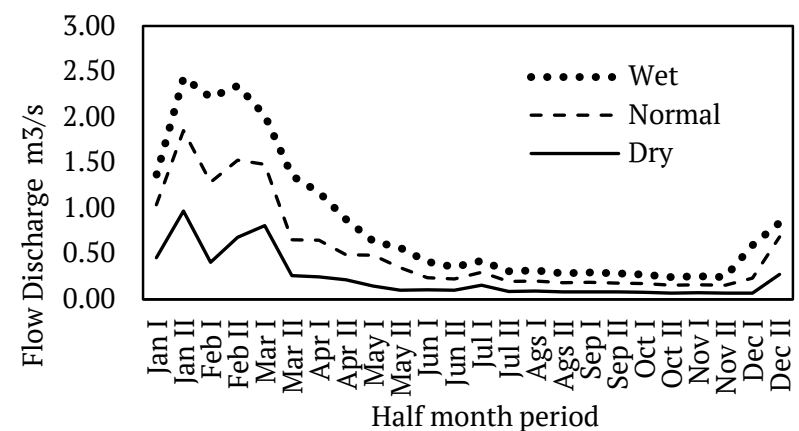

Figure 6. Distribution of flow discharge in half month period

\subsection{Analysis of Water Release Optimization}

A pattern of irrigation water need is described as a ratio between plant area and water need. It means that if the program just allows the plant area in the first planting season (MT I) is 237 ha, the next planting season must be 237 ha with different water need in every planting season following the age and type of plant. 
Table 6. Optimization results and water supply reliability

\begin{tabular}{|c|c|c|c|c|c|c|c|c|c|}
\hline \multirow[b]{2}{*}{ No. } & \multirow{2}{*}{$\begin{array}{l}\text { Half month } \\
\text { period }\end{array}$} & \multicolumn{2}{|c|}{ Target release } & \multicolumn{2}{|c|}{ Mean actual release } & \multicolumn{2}{|c|}{ SOR method } & \multicolumn{2}{|c|}{ Linear program } \\
\hline & & Irrigation & $\begin{array}{l}\text { Raw } \\
\text { water }\end{array}$ & Irrigation & Raw water & RAI & RAB & RAI & RAB \\
\hline 1 & Dec I & 0.197 & 0.013 & 0.171 & 0.013 & \multirow{24}{*}{$81.55 \%$} & \multirow{24}{*}{$80.08 \%$} & \multirow{24}{*}{$100 \%$} & \multirow{24}{*}{$100 \%$} \\
\hline 2 & Dec II & 0.409 & 0.014 & 0.354 & 0.014 & & & & \\
\hline 3 & Jan I & 0.315 & 0.013 & 0.271 & 0.013 & & & & \\
\hline 4 & Jan II & 0.327 & 0.014 & 0.281 & 0.014 & & & & \\
\hline 5 & Feb I & 0.317 & 0.013 & 0.269 & 0.013 & & & & \\
\hline 6 & Feb II & 0.276 & 0.012 & 0.271 & 0.012 & & & & \\
\hline 7 & Mar I & 0.281 & 0.013 & 0.273 & 0.013 & & & & \\
\hline 8 & Mar II & 0.146 & 0.013 & 0.142 & 0.013 & & & & \\
\hline 9 & Apr I & 0.224 & 0.013 & 0.224 & 0.013 & & & & \\
\hline 10 & Apr II & 0.391 & 0.014 & 0.343 & 0.014 & & & & \\
\hline 11 & May I & 0.336 & 0.013 & 0.303 & 0.013 & & & & \\
\hline 12 & May II & 0.308 & 0.013 & 0.267 & 0.013 & & & & \\
\hline 13 & Jun I & 0.302 & 0.013 & 0.267 & 0.013 & & & & \\
\hline 14 & Jun II & 0.323 & 0.014 & 0.280 & 0.014 & & & & \\
\hline 15 & Jul I & 0.251 & 0.013 & 0.222 & 0.013 & & & & \\
\hline 16 & Jul II & 0.136 & 0.014 & 0.120 & 0.014 & & & & \\
\hline 17 & Aug I & 0.162 & 0.013 & 0.146 & 0.013 & & & & \\
\hline 18 & Aug II & 0.172 & 0.013 & 0.155 & 0.013 & & & & \\
\hline 19 & Sep I & 0.121 & 0.013 & 0.121 & 0.013 & & & & \\
\hline 20 & Sep II & 0.183 & 0.014 & 0.176 & 0.014 & & & & \\
\hline 21 & Oct I & 0.249 & 0.013 & 0.218 & 0.013 & & & & \\
\hline 22 & Oct II & 0.257 & 0.013 & 0.219 & 0.013 & & & & \\
\hline 23 & Nov I & 0.182 & 0.013 & 0.163 & 0.013 & & & & \\
\hline 24 & Nov II & 0.093 & 0.014 & 0.093 & 0.014 & & & & \\
\hline
\end{tabular}

Although the water release of embung can be designated to serve both irrigational sector and raw water supply, the irrigational sector is on the first priority which means that the water release is targeted to serve irrigation area through irrigation intake prior to supplying raw water need.

Table 6 shows the result of optimization analysis using linear program. Comparing to the simulation results of water release obtained from the SOR method, linear program yields higher results with the variation of $k$, the value of embung reliability ranged between 0.70 and 1.00. Overall, the reliability of embung providing water irrigation increases from $81.55 \%$ to $100 \%$, while for the case of raw water, it increases from $80.09 \%$ to $100 \%$.

\section{CONCLUSIONS AND SUGGESTIONS}

\subsection{Conclusions}

Based on the results of the research, some conclusions can be summarized as follows.

a) Water balance of the existing condition indicates that the volume of the cumulative deficit was 1.105 MCM. To overcome this deficit, it is necessary to study the improvement of weir into a storage area.
The water balance with embung shows 3.477 MCM of a cumulative surplus volume. Thus, potential water utilization of Sadar Watershed is increased.

b) Simulation result of water regulation with SOR method shows the reliability of water supply for irrigation and domestic purpose has not reached the target of $95 \%$. Water supply reliability for irrigation is $81.55 \%$, while for domestic is $80.09 \%$. The application of the simulation model of the water embankment release method of SOR has not yet produced the optimum targeted condition. Therefore, to obtain optimal results, a study on the optimization of reservoir utilization is required.

c) The optimization result using a linear program method shows the reliability of embung providing irrigation water, and domestic water can reach $100 \%$ for $k=0.70-0.95$ factor in normal year condition. Reliability of water supplied from embung to irrigation and domestic in dry condition reach $100 \%$ for factor $k=0.70-0.75$, while in wet year condition, it is $100 \%$ for factor $\mathrm{k}=0.70-1.00$. Generally, the development plan of Embung Jinggring can increase the capacity of irrigation water supply as well as domestic water. 


\subsection{Suggestions}

Suggestions can be submitted for further research are as follows.

a) In this study, the natural phenomenon is simplified. A period operation is assumed half a month. This can be done with a daily period, for example, every 10 days or shorter.

b) The function of optimization objectives can be developed for example for flood control to reduce high discharge during the rainy season or if possible enhanced its function for hydropower.

c) The use of advanced methods is essential for further research.

\section{REFERENCES}

Direktorat Bina Teknik, 2003. Pedoman Penentuan Kebutuhan Air Baku Rumah Tangga Perkotaan dan Industri [Guideline for Determination of Raw Water Need for Household, Domestic, and Industry], Jakarta: Department of Housing and Regional Infrastructure.

Direktorat Jendral Pengairan, 2010. Standar Perencanaan Irigasi Kriteria Perencanaan Bagian Jaringan Irigasi KP-01 [Design Standard of Irrigation for Criteria Design of Irrigation Network], Jakarta: Ministry of Public Works.

Gunawan, G., 2005. Evaluasi Pola Operasi Multi Waduk Sebagai Upaya Untuk Memberikan Nilai Tambah Pada Waduk Yang Terletak Secara Serial [Evaluation of Multipurpose Reservoir Operation for Giving Additional Value in Series Reservoirs]. Jurnal Teknik Sipil, Universitas Bengkulu, pp. 29-37.

Hartini, R. K., 2013. Pengembangan Model Optimasi Waduk Pandanduri untuk Pemenuhan Kebutuhan Air Irigasi di Lombok Nusa Tenggara Barat [Development of Optimization Model of Pandanduri Reservoir for Water Irrigation Requirement in Lombok, West Nusa Tenggara], Yogyakarta: Master Thesis Report. Posgraduate Program of Department of Civil and Environmental Engineering. Universitas Gadjah Mada.
Jayadi, R., 2000. Optimasi dan Simulasi Pengembangan Sumberdaya Air [Optimization and Simulation of Water Resources Development], Yogyakarta: Lecturer's Note. Postgraduate Program of Department of Civil and Environmental Engineering, Universitas Gadah Mada.

Jayadi, R., 2012. Sumber Daya Air [Water Resources], Yogyakarta: Lecturer's Note. Department of Civil and Environmental Engineering, Unviersitas Gadjah Mada.

Loucks, D. P., Stedinger, J. R. \& Haith, , D. A., 1981. Water Resources System Planning and Analysis. New Jersey: Pretince Hall.

Mock, F. J., 1973. Land Capability-Appraisal Indonesia Water-Availability Appraisal. Bogor: UNDP/FAO.

Prasetyo, A. R., 2000. Kursus Singkat Sistem Sumberdaya Air dalam Otonomi Daerah [Short Course of Water Resources System in Regional Autonomy], Yogyakarta: Lecturer's Note. Department of Civil and Environmental Engineering, Universitas Gadjah Mada.

Rahmadana, A., 2013. Studi Pengaturan Air untuk Meningkatkan Kinerja Waduk Batutegi [Water Management Study to Enhance the Performance of Batutegi Reservoir], Yogyakarta: Postgraduate Program of CIvil and Environmental Engineering Department, Universitas Gadjah Mada.

Setiawan, A., 2007. Kajian Keandalan Waduk Sempor. Jurnal Teknik Sipil, Universitas Atma Jaya, pp. 279-286.

Tarigan, A., 2001. Optimasi Pemanfaatan Air Waduk Kedung Ombo dengan Program Linier [Optimization of the Utilization of Kedung Ombo Reservoir using Linear Program], Yogyakarta: Postgraduate Program of Civil Engineering Department, Universitas Diponegoro.

Triatmodjo, B., 2008. Hidrologi Terapan [Applied Hydology]. Yogyakarta: Beta Offset. 